Jerzy Janczewski* (D) https://orcid.org/0000-0002-6994-2683 e-mail: jerzyjanczewski@poczta.onet.pl

Danuta Janczewska * (D) https://orcid.org/0000-0003-1013-5665

e-mail:janczewska@republika.pl

\title{
Problemy bezpieczeństwa urządzeń transportu osobistego
}

https://doi.org/10.25312/2391-5129.30/2020_09jjdj

\begin{abstract}
Urządzenia transportu osobistego najczęściej wykorzystuje się na dojazdy lub powroty z pracy, szkoły, uczelni, dojazdy do urzędów, jako połączenie $z$ transportem publicznym, w celach towarzyskich i rekreacyjnych. UTO służą również do przemieszczania się po korytarzach biur, halach targowych i przemysłowych. Kluczowe wyzwania dla takich form przemieszczania związane są z przystępnością infrastruktury, dopuszczalną prędkością, wrażliwością na warunki pogodowe, brakiem przestrzeni dla bagażu i pasażera, ładowaniem akumulatorów, korzystnym modelem biznesowym i operacyjnym. Pojawiają się również istotne wątpliwości co do zgodności z prawem i wyzwania związane z bezpieczeństwem pieszych i pozostałych użytkowników ruchu drogowego, a ostatnio także bezpieczeństwem epidemiologicznym.

Artykuł ma na celu przedstawienie niektórych aspektów bezpieczeństwa użytkowania urządzeń transportu osobistego zarówno z perspektywy ruchu drogowego, jak i z perspektywy bezpieczeństwa epidemicznego. Praca ma charakter opisowy i prezentuje cztery aktualne i tym samym istotne zagadnienia dotyczące urządzeń transportu osobistego. Pierwsze to uwarunkowania prawne definiowania i korzystania z UTO, drugie to przytoczenie badań popularności tych urządzeń w Polsce, zaś dwa pozostałe dotyczą wybranych problemów bezpieczeństwa ich użytkowania.
\end{abstract}

Słowa kluczowe: urządzenia transportu osobistego, mikromobilność, mikropojazdy, bezpieczeństwo

${ }^{*}$ Dr inż. Jerzy Janczewski - adiunkt w Katedrze Systemów Transportu na Wydziale Informatyki, Zarządzania i Transportu Akademii Humanistyczno-Ekonomicznej w Łodzi.

${ }^{* *}$ Dr inż. Danuta Janczewska - adiunkt, Społeczna Akademia Nauk w Łodzi. 


\section{Wstęp}

Urządzenia transportu osobistego (UTO) ułatwiają przemieszczanie się osób w miastach, są coraz liczniejsze, przybywa ponadto nowych rozwiązań konstrukcyjnych w dziedzinie UTO. W miastach są one kojarzone głównie z wypożyczanymi na minuty e-hulajnogami, ale UTO to także około 200 tysięcy pojazdów znajdujących się w posiadaniu prywatnych użytkowników (Polska może być krajem UTO. Badanie pokazało bardzo pozytywny stosunek do elektrycznej mobilności, 2020). Przykładowo w Warszawie już w zeszłym sezonie co dwudziestym użytkowanym pojazdem w porównaniu do użytkowanych rowerów była elektryczna hulajnoga. Pamiętajmy, że to dopiero początki obecności hulajnóg w miastach, gdyż urządzenia transportu osobistego - zarówno prywatne, jak i współdzielone - funkcjonują w komunikacji zaledwie od kilku sezonów.

Urządzenia transportu osobistego oferują nowy i osobliwy sposób podróżowania osób w mieście oparty na takich atrybutach, jak swoboda, dostępność, kontrola środka transportu, niska cena, ekologiczność, przyjemność z użytkowania i wrażenia.

O popularności tego sposobu przemieszczania się świadczy zainteresowanie UTO znanych koncernów motoryzacyjnych ${ }^{1}$, rosnąca $\mathrm{z}$ roku na rok ich sprzedaż oraz liczba wypożyczeń w miastach, a także w kurortach wypoczynkowych (zob. E-hulajnogi. Sharing. Polska. Trzeci kwartał 2020 roku, 2020). Rozwój ten powoduje, że wskazane urządzenia stają się coraz bardziej dostępne i popularne.

Urządzenia transportu osobistego najczęściej wykorzystuje się na dojazdy lub powroty z pracy, szkoły, uczelni, dojazdy do urzędów, jako połączenie z transportem publicznym, w celach towarzyskich i rekreacyjnych. UTO służą również do przemieszczania się po korytarzach biur, halach targowych i przemysłowych.

Kluczowe wyzwania dla takich form przemieszczania związane są z przystępnością infrastruktury, dopuszczalną prędkością, wrażliwością na warunki pogodowe, brakiem przestrzeni dla bagażu i pasażera, ładowaniem akumulatorów, korzystnym modelem biznesowym i operacyjnym. Pojawiają się również istotne wątpliwości co do zgodności z prawem i wyzwania związane z bezpieczeństwem pieszych i pozostałych użytkowników ruchu drogowego, a ostatnio także bezpieczeństwem epidemicznym.

Przewiduje się, że popularność UTO jest dopiero w początkowym stadium rozwoju, a najbliższe lata przyniosą jeszcze większy popyt na tego rodzaju środki przemieszczania się.

Artykuł ma na celu przedstawienie niektórych aspektów bezpieczeństwa użytkowania urządzeń transportu osobistego zarówno z perspektywy ruchu drogowego, jak i z perspektywy bezpieczeństwa epidemicznego. Praca ma charakter opisowy

${ }^{1}$ Potencjał elektrycznych hulajnóg i deskorolek doceniły największe koncerny motoryzacyjne. Na rynku można znaleźć urządzenia takich marek, jak na przykład Fiat czy Kawasaki (zob. Planujesz zakup e-pojazdu - przeczytaj koniecznie projekt ustawy o UTO, 2020). 
i prezentuje cztery aktualne i tym samym istotne zagadnienia dotyczące urządzeń transportu osobistego. Pierwsze to uwarunkowania prawne związane $\mathrm{z}$ definiowaniem i korzystaniem z UTO, drugie to przytoczenie badań popularności tych urządzeń w Polsce, zaś dwa pozostałe podejmują niektóre problemy bezpieczeństwa ich użytkowania.

\section{Urządzenia transportu osobistego (UTO) - uwarunkowania prawne}

Urządzenia transportu osobistego ${ }^{2}$ oczekują na przepisy określające zasady korzystania, a także na oficjalne zdefiniowanie. W obowiązującej w Polsce ustawie Prawo o ruchu drogowym UTO nie są zdefiniowane ani sklasyfikowane. Prowadzi to do paradoksalnej sytuacji, w której z jednej strony promuje się i wdraża systemy wypożyczalni elektrycznych hulajnóg, a z drugiej strony brakuje możliwości korzystania $\mathrm{z}$ nich. W obecnym stanie prawnym poruszanie się urządzeniami typu elektryczna hulajnoga czy segway po drogach publicznych, w strefach zamieszkania oraz w strefach ruchu jest zabronione. Hulajnogami nie powinno się też jeździć po chodnikach dla pieszych i nie wolno korzystać ze ścieżek rowerowych. Według aktualnie istniejącego prawa użytkownik hulajnogi jest traktowany jako pieszy, zatem powinien mieć możliwość poruszania się po infrastrukturze przeznaczonej dla pieszych, ale z prędkością pieszego, co oczywiście przez użytkowników nie jest praktykowane.

Ministerstwo Infrastruktury opublikowało i poddało konsultacjom kolejną wersję projektu ustawy Prawo o ruchu drogowym w sprawie UTO wraz z jej uzasadnieniem (zob. Projekt z dnia 12 maja 2020 r. Ustawy o zmianie Ustawy-Prawo o ruchu drogowym oraz niektórych innych ustaw, 2020: 1-13). Syntetyczne zestawienie propozycji zmian w stosunku do Ustawy z dnia 20 czerwca 1997 r. - Prawo o ruchu drogowym można też znaleźć w publikacji tygodnika „Prawo Drogowe@news” (Jest szansa na uporządkowanie bałaganu hulajnogowego, 2020).

Projektowane przepisy wprowadzają do Ustawy z dnia 20 czerwca 1997 r. Prawo o ruchu drogowym (Dz.U. 2020, poz. 110 z późn. zm.), zwanej dalej ustawą - Prawo o ruchu drogowym, rozwiązania mające na celu uporządkowanie ruchu urządzeń transportu osobistego (takich jak hulajnoga elektryczna) na drogach publicznych (Projekt z dnia 12 maja 2020 r. Ustawy o zmianie Ustawy-Prawo o ruchu drogowym oraz niektórych innych ustaw, 2020: 5).

Projektowana regulacja obejmuje między innymi kwestie statusu prawnego urządzenia transportu osobistego (a tym samym jego użytkownika - kierującego tym urządzeniem), określenie części drogi przeznaczonych do ruchu urządzeń transportu osobistego, dopuszczalnej prędkości wskazanych urządzeń, uprawnień do kierowania

${ }^{2}$ Urządzenia transportu osobistego zalicza się do środków transportu mikromobilności (zob. Janczewski, 2020; Janczewski, Janczewska, 2020). W pracy określenia UTO używa się zamiennie $\mathrm{z}$ terminem mikropojazd. 
oraz minimalnego wieku osób poruszających się przy użyciu tych urządzeń (Projekt $z$ dnia 12 maja 2020 r. Ustawy o zmianie Ustawy - Prawo o ruchu drogowym oraz niektórych innych ustaw, 2020).

W projektowanych przez ministerstwo przepisach hulajnoga elektryczna, deskorolka elektryczna, elektryczne urządzenia samopoziomujące i inne urządzenia o podobnej konstrukcji wyposażone w napęd elektryczny, przeznaczone do transportu osób jest nazywane urządzeniem transportu osobistego.

Projektowane przepisy wprowadzają do ustawy - Prawo o ruchu drogowym uszczegółowioną definicję urządzenia transportu osobistego, wskazując, że jest to pojazd konstrukcyjnie przeznaczony do poruszania się wyłącznie przez kierującego znajdującego się na tym urządzeniu oraz określają dla tego urządzenia maksymalne wymiary (szerokość nieprzekraczającą w ruchu 0,9 m, długość nieprzekraczającą $1,25 \mathrm{~m}$ ) i maksymalną prędkość jazdy ograniczoną konstrukcyjnie do $25 \mathrm{~km} / \mathrm{h}$, jak również źródło napędu (napęd elektryczny). Projektodawca nie przewidział możliwości stosowania innych rodzajów napędu niż elektryczny - mając na względzie potrzebę ograniczenia zanieczyszczenia powietrza przez silniki spalinowe, a także to, że obecnie poza silnikami elektrycznymi inne rodzaje napędu dla takich urządzeń nie są powszechnie dostępne.

Projektowane regulacje powodują, że urządzenie spełniające wymagania zawarte w definicji UTO będzie korzystało z definicji roweru. Konsekwencją przyjętego rozwiązania jest na przykład fakt, że zastosowanie w organizacji ruchu na drodze znaku zakazu B-9 ,zakaz wjazdu rowerów” oznacza także zakaz wjazdu urządzenia transportu osobistego.

Objęcie urządzenia transportu osobistego definicją roweru w konsekwencji również powoduje, że kierujący tym urządzeniem może korzystać z infrastruktury przeznaczonej dla rowerów (droga dla rowerów, pas ruchu dla rowerów, przejazd dla rowerzystów) i jest obowiązany posiadać uprawnienia do kierowania takie same jak w przypadku roweru (m.in. karta rowerowa). $Z$ tego względu osoby poniżej 10. roku życia (granica wieku dla możliwości uzyskania karty rowerowej) nie mogą samodzielnie, bez opieki osoby dorosłej korzystać z urządzeń transportu osobistego (Projekt z dnia 12 maja 2020 r. Ustawy o zmianie Ustawy - Prawo o ruchu drogowym oraz niektórych innych ustaw, 2020: 6).

Kierującego urządzeniem transportu osobistego będzie obowiązywało zróżnicowanie prędkości ruchu w zależności od infrastruktury drogowej, z której korzysta podczas jazdy. Zgodnie z projektowanym przepisem prędkość dopuszczalna dla takich urządzeń wynosi:

- na chodniku albo drodze dla pieszych - prędkość pieszego,

- na jezdni, pasie ruchu dla rowerów lub drodze dla rowerów - $25 \mathrm{~km} / \mathrm{h}$.

Natomiast prędkość dopuszczalna urządzenia transportu osobistego w strefie zamieszkania nie może być większa niż $20 \mathrm{~km} / \mathrm{h}$.

W ramach konsultacji społecznych projektu zgłoszono szereg uwag do jego zapisów. Uwagi zgłosiły zarówno osoby fizyczne, jak i prawne reprezentujące różne 
podmioty bezpośrednio lub pośrednio powiązane z użytkowaniem UTO. Było to około 100 głosów. Przykładowo projekt nie uwzględnia urządzeń napędzanych siłą mięśni ludzkich (zob. PKD o UTO: Nie tylko elektryczne, 2020). Aktualnie (tj. na dzień 22 lipca 2020 roku) oczekuje się odniesienia wnioskodawcy do uwag oraz odrębnej konferencji w ramach podmiotów publicznych (zob. Stanowiska zgłoszone w ramach konsultacji publicznych, 2020).

\section{Popularność UTO w Polsce w świetle badań IBRIS}

W czerwcu 2020 roku opublikowano raport z pierwszego w Polsce badania wizerunkowego urządzeń transportu osobistego (UTO). Inicjatorzy badania chcieli sprawdzić, jaki stosunek do tychże urządzeń ma polska opinia publiczna.

Badanie zostało przeprowadzone w marcu 2020 roku przez Instytut Badań Rynkowych i Społecznych (IBRIS). Raport przygotowano do celów informacyjnych na podstawie ogólnopolskiego badania $(n=1100)$ zrealizowanego metodą CATI. Raport zleciło i wydało stowarzyszenie Mobilne Miasto, zaś tytuł raportu UTO-entuzjaści wyprzedził spodziewane jego rezultaty (UTO-entuzjaści. Urzadzenia transportu osobistego i ich przyszłość w ocenie Polaków, 2020).

Wyniki przedstawione w raporcie UTO-entuzjaści wskazują, że 91\% respondentów liczy na to, iż urządzenia transportu osobistego będą miały dobry wpływ na jakość powietrza w miastach, 89\% badanych osób sądzi, że UTO mogą być równie bezpieczne jak rower, $83 \%$ badanych jest zdania, że na krótkim odcinku urządzenia te mogą zastąpić samochód, u 75\% respondentów pojazdy UTO budzą pozytywne odczucia, zaś $72 \%$ respondentów uważa, że pomogą one w rozładowaniu korków w miastach, podobnie 72\% badanych uważa, że popularność UTO jako środka transportu będzie rosła, a 48\% twierdzi, że UTO w przyszłości ma szansę być masowym środkiem komunikacji w polskich miastach. Pokazano to na rysunku 1. 


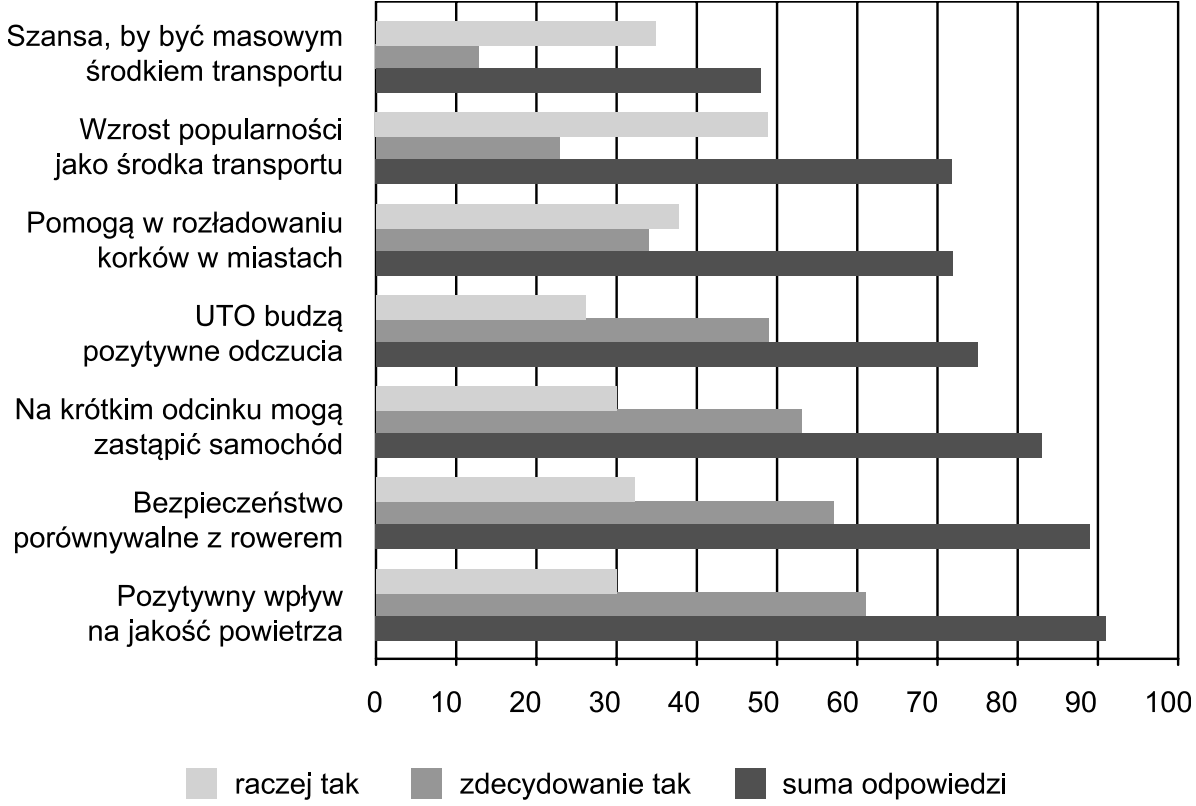

Rysunek 1. Opinie respondentów badania na temat urządzeń transportu osobistego wyrażone $w$ procentach odpowiedzi

Źródło: opracowanie własne na podstawie raportu UTO-entuzjaści. Urządzenia transportu osobistego i ich przyszłość w ocenie Polaków, 2020.

Zdaniem stowarzyszenia Mobilne Miasto przedmiotowe badanie pokazuje rzeczywisty stosunek do UTO całego społeczeństwa, a nie wyrywkowe spojrzenie indywidualnych osób, na przykład niektórych dziennikarzy lub samorządowców nie zawsze przychylnych UTO.

Wyniki tego badania wskazują, że Polacy są bardzo otwarci na nowe środki lokomocji w miastach, podchodzą do nich z zaufaniem i optymizmem, widząc w tych innowacyjnych systemach ogromną szansę dla swoich miast. Respondenci są przekonani, że UTO pomogą rozwiązywać problemy kongestii, zagęszczenia ruchu i zanieczyszczenia powietrza. $Z$ badania wynika też, że właśnie te kwestie respondenci uważają za kluczowe dla miast, oczekując aktywniejszych działań władz w tym obszarze.

\section{Bezpieczeństwo UTO}

Podczas korzystania z urządzeń transportu osobistego, jak i pozostałych form mobilności może dochodzić do niebezpiecznych zachowań użytkowników oraz do zdarzeń drogowych i wypadków, również śmiertelnych, które mają bezpośredni wpływ na bezpieczeństwo ruchu drogowego. 
Z danych Austin Public Health Department oraz Centers for Disease Control and Prevention (USA) wynika, że jeden na 5000 przejazdów pojazdem elektrycznym zakończył się kontuzją użytkownika. W ciągu tylko jesieni 2018 roku zostało poszkodowanych 190 osób, przy czym tylko jedna z nich miała kask ochronny głowy. Autorzy badania wskazują, że kask powinien być obowiązkowy dla wszystkich osób wykorzystujących do przemieszczania się mikropojazdy, gdyż utrata równowagi, wypadek to sytuacje, w których ochrona głowy może przesądzić o rozmiarze szkód.

Wśród osób, które uległy wypadkowi, 48\% miało uraz głowy, 70\% uszkodziło sobie kończyny górne, zaś 55\% - dolne, 35\% doznało złamania kości, a 19\% - więcej niż jednej (nie licząc palców) (Gitlin, 2019; zob. Dockless Electric Scooter-Related Injuries Study, 2018: 1-12).

Choć trudno jest wskazać jednoznaczną przyczynę tych wypadków i nie da się znaleźć wspólnego mianownika dla nich wszystkich, to, jak pisze J. Szczęsny (2019), wiele wskazuje na kontekst bezpieczeństwa UTO.

W Polsce, zwłaszcza w sezonie wiosenno-letnim, obserwuje się w Szpitalnych Oddziałach Ratunkowych rosnącą liczbę przypadków poważnych urazów związanych z użytkowaniem UTO (zob. Szymaniak, 2020). Niemniej w naszym kraju zagadnienie bezpieczeństwa mikromobilności nie doczekało się jeszcze systematycznych badań. Ujęcia tej kwestii dotyczą tylko rowerów.

Mikropojazdy z racji swej natury nie zapewniają bezpieczeństwa podczas kolizji czy wypadku i w żaden sposób nie chronią kierującego w sytuacji wywrócenia się i upadku. Ponadto w razie najechania na nierówność jezdni lub chodnika kierującemu - ze względu na małą średnicę kół mikropojazdów - bardzo trudno zapanować nad pojazdem. Użytkujące je osoby, zwłaszcza w przypadku pojazdów wypożyczanych na określony czas, najczęściej nie stosują takiego wyposażenia ochronnego, jak kask i ochraniacze na najbardziej podatne na uraz części ciała. Dodając do tego fakt, że UTO mogą rozwijać relatywnie duże prędkości, a oprócz tego są prawie bezgłośne, a więc trudniej zauważalne przez innych uczestników ruchu, to ich użytkowanie wiąże się z określonym ryzykiem i może zagrażać bezpieczeństwu ruchu (Śmierć na hulajnodze. To gdzie utknęła ustawa?, 2020).

Można zatem wyróżnić kilka potencjalnych zagrożeń, które niesie za sobą użytkowanie UTO, zwłaszcza najbardziej popularnych elektrycznych hulajnóg, a mianowicie:

- zbyt duża prędkość i niedostosowanie jej do warunków otoczenia, zagrożenie charakterystyczne dla użytkowania większości pojazdów,

- użytkowanie w niedozwolonych miejscach, obecnie UTO można poruszać się tylko po chodnikach, tak jak czynią to piesi, korzystanie z dróg, szlaków turystycznych $^{3}$ i ulic jest niebezpieczne i prawnie zabronione,

${ }^{3}$ Przykładem może być decyzja władz Parku Tatrzańskiego zabraniająca poruszania się po szlakach hulajnogami elektrycznymi (Bobek, 2020). 
- niewłaściwie dobrane UTO, na przykład hulajnoga elektryczna powinna posiadać odpowiednio szeroki podest, odpowiednią masę własną i moc silnika, ogranicznik prędkości, dostateczny udźwig i regulowaną kierownicę, opony im są szersze, tym lepiej pokonują nierówności drogi, dobrym rozwiązaniem jest też wygodne siedzisko,

- niewłaściwe parkowanie, szczególnie dotyczy hulajnóg współdzielonych pozostawianych w przypadkowych miejscach, niekiedy w pozycji leżącej,

- sytuacje patologiczne i skrajne, przejmowanie kontroli nad aplikacjami przez osoby trzecie, dewastowanie sprzętu, wadliwe podzespoły, na przykład akumulator.

Reasumując, aby ograniczyć potencjalne zagrożenia wynikające z użytkowania UTO, należy przestrzegać kilku podstawowych zasad, takich jak: korzystanie z kasku i ochraniaczy, przestrzeganie bezpiecznej prędkości, nieporuszanie się po jezdniach i zatłoczonych chodnikach, zwracanie uwagi na pieszych i pamiętanie o regule ograniczonego zaufania, korzystanie z UTO tylko w pojedynkę, dobór pojazdu odpowiedniego do wzrostu i wagi, optymalna moc silnika lub możliwość ograniczenia jego prędkości, parkowanie tylko w bezpiecznych miejscach na uboczu (Poradnik. Bezpieczna jazda na hulajnodze, 2020).

Międzynarodowe Forum Transportu zauważa, że wzorce ruchu miejskiego stają w obliczu rozwoju mikromobilności, która oznacza wykorzystanie na krótkie dystanse elektrycznych hulajnóg, e-rowerów, zmotoryzowanych deskorolek i innych lekkich osobistych urządzeń ułatwiających poruszanie się, podobnie jak tradycyjnych rowerów (10 zaleceń dotyczacych bezpiecznej mikromobilności, 2020).

Tabela 1. 10 zaleceń zapewniających większe bezpieczeństwo użytkowników UTO i pieszych

\begin{tabular}{|c|l|l|}
\hline Lp. & \multicolumn{1}{|c|}{ Zalecenie } & \multicolumn{1}{c|}{ Komentarz do realizacji zalecenia } \\
\hline 1 & $\begin{array}{l}\text { Wyznaczenie } \\
\text { przestrzeni ochronnej }\end{array}$ & $\begin{array}{l}\text { Utwórz dla mikromobilności chronioną i połączoną sieć } \\
\text { infrastruktury. Można to zrealizować poprzez uspokojenie ruchu } \\
\text { lub stworzenie przestrzeni przeznaczonej dla mikromobilności. } \\
\text { Mikropojazdy powinny mieć zakaz poruszania się po chodnikach } \\
\text { lub powinny je obowiązywać ograniczenia prędkości. }\end{array}$ \\
\hline 2 & $\begin{array}{l}\text { Skupienie uwagi na } \\
\text { pojazdach silnikowych }\end{array}$ & $\begin{array}{l}\text { Stosowanie e-napędów nie powinno odwracać uwagi od } \\
\text { zagrożeń, jakie pojazdy silnikowe stanowią dla wszystkich innych } \\
\text { użytkowników dróg. W przypadku gdy niechronieni użytkownicy } \\
\text { dróg dzielą przestrzeń z pojazdami silnikowymi, ograniczenie } \\
\text { prędkości powinno wynosić 30 km/h lub mniej. }\end{array}$ \\
\hline 3 & $\begin{array}{l}\text { Dostosowanie } \\
\text { prawa dla wolno } \\
\text { poruszających się } \\
\text { mikropojazdów } \\
\text { podobnie jak dla } \\
\text { rowerów }\end{array}$ & $\begin{array}{l}\text { Aby zapobiec nadmiernej regulacji prawnej, wolno jeżdżące } \\
\text { mikropojazdy, takie jak hulajnogi elektryczne i rowery elektryczne, } \\
\text { należy traktować jak rowery. Szybsze mikropojazdy powinny } \\
\text { podlegać przepisom obowiązującym dla motorowerów. Wtedy } \\
\text { mikromobilność może spowodować, że podróże miejskie staną } \\
\text { się bardziej zrównoważone. }\end{array}$ \\
\hline
\end{tabular}




\begin{tabular}{|c|c|c|}
\hline Lp. & Zalecenie & Komentarz do realizacji zalecenia \\
\hline 4 & $\begin{array}{l}\text { Zbieranie danych } \\
\text { dotyczących } \\
\text { podróży i wypadków } \\
\text { mikropojazdów }\end{array}$ & $\begin{array}{l}\text { Kodyfikacja statystyczna typów pojazdów musi zostać } \\
\text { zaktualizowana i zharmonizowana. Policja i szpitale powinny } \\
\text { gromadzić dokładne dane o wypadkach. Agencje bezpieczeństwa } \\
\text { drogowego powinny gromadzić dane dotyczące podróży za } \\
\text { pośrednictwem operatorów, ankiet na temat podróży i obserwacji } \\
\text { na ulicach. Obecnie niewiele wiadomo o bezpieczeństwie } \\
\text { mikropojazdów. }\end{array}$ \\
\hline 5 & $\begin{array}{l}\text { Proaktywne zarządzanie } \\
\text { bezpieczeństwem sieci } \\
\text { ulicznych }\end{array}$ & $\begin{array}{l}\text { Wiele współużytkowanych mikropojazdów posiada czujniki ruchu } \\
\text { i GPS. Mogą one dostarczyć przydatnych danych na temat } \\
\text { uszkodzeń infrastruktury, upadków i innych zdarzeń, a także } \\
\text { wypadków. Władze i operatorzy powinni współpracować ze } \\
\text { sobą i używać tych danych do monitorowania sytuacji i dbania } \\
\text { o składniki systemu. }\end{array}$ \\
\hline 6 & $\begin{array}{l}\text { Uwzględnienie } \\
\text { mikromobilności } \\
\text { w szkoleniach } \\
\text { użytkowników dróg }\end{array}$ & $\begin{array}{l}\text { Szkolenie kierowców samochodów osobowych, autobusów } \\
\text { i ciężarówek w celu uniknięcia wypadków z kierowcami } \\
\text { mikropojazdów powinno być obowiązkowe. Szkolenie cykliczne } \\
\text { powinno być częścią programu nauczania. Programy szkoleniowe } \\
\text { należy regularnie oceniać i aktualizować. }\end{array}$ \\
\hline 7 & $\begin{array}{l}\text { Kontrole kierujących } \\
\text { wszystkich typów } \\
\text { pojazdów po spożyciu } \\
\text { alkoholu i pozostałych } \\
\text { środków odurzających } \\
\text { oraz po przekroczeniu } \\
\text { prędkości }\end{array}$ & $\begin{array}{l}\text { Władze powinny określić i egzekwować ograniczenia } \\
\text { prędkości, używania alkoholu i narkotyków wśród wszystkich } \\
\text { uczestników ruchu. Obejmuje to nie tylko kierowców pojazdów } \\
\text { mechanicznych, lecz także użytkowników wszystkich środków } \\
\text { transportowych, również mikromobilności. }\end{array}$ \\
\hline 8 & $\begin{array}{l}\text { Likwidowanie czynników } \\
\text { zachęcających } \\
\text { użytkowników } \\
\text { mikromobilności do } \\
\text { pośpiechu }\end{array}$ & $\begin{array}{l}\text { Operatorzy współdzielonych flot mikromobilności powinni } \\
\text { spowodować, aby ich mechanizmy cenowe nie zachęcały } \\
\text { wypożyczających do podejmowania zbędnego ryzyka. Na } \\
\text { przykład wynajem na minuty może być zachętą do przyspieszania } \\
\text { lub ignorowania przepisów ruchu drogowego. }\end{array}$ \\
\hline 9 & $\begin{array}{l}\text { Doskonalenie } \\
\text { konstrukcji } \\
\text { i właściwości jezdnych } \\
\text { mikropojazdów }\end{array}$ & $\begin{array}{l}\text { Producenci powinni podnosić poziom stabilności i przyczepności } \\
\text { mikropojazdów. Rozwiązań można poszukać w oponach } \\
\text { pneumatycznych, większym rozmiarze kół, geometrii ramy itp. } \\
\text { Lampki sygnalizacyjne (kontrolki) powinny być obowiązkowe, } \\
\text { a przewody hamulcowe lepiej chronione. }\end{array}$ \\
\hline 10 & $\begin{array}{l}\text { Ograniczanie } \\
\text { ryzyka związanego } \\
\text { z operacjami } \\
\text { zbiórki i załadunku } \\
\text { współdzielonych } \\
\text { mikropojazdów }\end{array}$ & $\begin{array}{l}\text { Wykorzystanie samochodów do zbiórki i przewożenia } \\
\text { współdzielonych mikropojazdów powinno być ograniczone, } \\
\text { gdyż dodatkowo zwiększają one ryzyko zdarzeń i wypadków } \\
\text { na ulicach. Miasta powinny przeznaczać miejsca parkingowe } \\
\text { dla takich mikropojazdów w pobliżu zatok dla samochodów } \\
\text { pomocniczych. }\end{array}$ \\
\hline
\end{tabular}

Źródło: opracowanie własne na podstawie 10 Recommendations for Safe Micromobility, 2020.

Opublikowany przez Międzynarodowe Forum Transportu raport na temat bezpieczeństwa UTO stwierdza, że (10 Recommendations for Safe Micromobility, 2020):

- użytkownicy hulajnóg elektrycznych nie są narażeni na znacznie większe ryzyko śmierci lub obrażeń w ruchu drogowym niż rowerzyści,

- pojazdy silnikowe uczestniczą w $80 \%$ śmiertelnych wypadków z hulajnogą elektryczną i rowerami, 
- ruch drogowy może być bezpieczniejszy, jeśli przemieszczanie się na hulajnogach elektrycznych, rowerach i innych mikropojazdach zastąpi podróż samochodem lub motocyklem,

- szybka ewolucja mikropojazdów zmusza rządy do wprowadzenia rozwojowych przepisów bezpieczeństwa.

Aby użytkownicy UTO i piesi nie stawali się ofiarami wypadków Międzynarodowe Forum Transportu w swoim raporcie prezentuje 10 zaleceń dla rządzących, urbanistów, operatorów i producentów, co pokazano w tabeli 1. Zalecenia te dotyczą tworzenia przestrzeni ochronnej dla mikromobilności, skoncentrowania się na pojazdach silnikowych, wprowadzenia takiego samego prawa dla wolno jeżdżących mikropojazdów jak dla rowerów, gromadzenia danych dotyczących podróży i wypadków z udziałem mikropojazdów, proaktywnego zarządzania bezpieczeństwem sieci ulicznych, uwzględnienia mikromobilności w szkoleniach, kontrolowania kierujących wszystkimi typami pojazdów, zwłaszcza po spożyciu alkoholu i pozostałych środków odurzających oraz po przekroczeniu prędkości, likwidowanie czynników zachęcających użytkowników mikromobilności do pośpiechu, doskonalenia konstrukcji i właściwości jezdnych mikropojazdów oraz ograniczania ryzyka związanego z operacjami zbiórki i załadunku współdzielonych pojazdów.

\section{UTO a bezpieczeństwo epidemiczne}

Problematyka bezpieczeństwa epidemicznego w transporcie jest stale aktualna, choć do czasu pojawienia się koronawirusa i wybuchu pandemii nie była tak widoczna jak obecnie. Szczególnie wrażliwy na zagrożenia wynikające z pandemii stał się transport zbiorowy, a konieczność dystansowania się i unikania przebywania w zatłoczonych przestrzeniach nie zachęca do korzystania z tej formy przemieszczania się. Sytuacja taka dostarcza organizatorom transportu zbiorowego dodatkowych utrudnień, z których na pierwszy plan wysuwają się problemy organizacyjne i techniczne wpływające na bezpieczne, czyli wolne od koronawirusa podróżowanie, nie bez znaczenia też pozostają problemy ekonomiczne.

Na czasie są i zapewne jeszcze długo nie doczekają się wyczerpujących odpowiedzi, takie pytania:

1. Jak koronawirus zmieni mobilność w Polsce?

2. Jak zachęcić pasażerów transportu publicznego do korzystania lub wręcz powrotu?

3. Na jakie zmiany technologiczne należy się przygotować?

4. Czy inwestycje w modelu PPP (partnerstwo publiczno-prywatne) są szansą dla samorządów stojących w obliczu problemów budżetowych?

5. Czy pandemia pogłębi problem wykluczenia transportowego? (Koronawirus pogrzebat mikromobilność? Ratunkiem bardziej dynamiczne podejście, 2020). 
Informacje $\mathrm{z}$ rynku wskazują na rosnące zainteresowanie pojazdami jednośladowymi, między innymi rowerami tradycyjnymi i rowerami z napędem elektrycznym. Już przed pandemią rower miejski zyskał na popularności i stał się dostępny we wszystkich polskich miastach. Pandemia koronawirusa spowodowała znaczny wzrost zainteresowania rowerami indywidualnymi. Producenci i sprzedawcy tych pojazdów odnotowali duże wzrosty sprzedaży. W maju 2020 roku w Polsce wyprodukowano 119 tysięcy rowerów. To oznacza wzrost o 33,4\% w stosunku do roku 2019. Niektóre ze sklepów wręcz podwoiły swoje wolumeny sprzedaży. Na znaczący wzrost zainteresowania Polaków jednośladami wskazują też dane z wyszukiwarek. Według Google Trends w ostatnich miesiącach tematów związanych z rowerami najczęściej poszukiwali zwłaszcza mieszkańcy województw śląskiego (które było jednym z największych w Polsce ognisk SARS-CoV-2), a także wielkopolskiego, dolnośląskiego, opolskiego i pomorskiego (Rowerowy boom w Polsce: Dystans plus wakacje w kraju, 2020).

Użytkowanie rowerów, hulajnóg i innych mikropojazdów już przed pandemią stało się preferowaną opcją przemieszczania się w wielu miastach na świecie. W czasie trwania pandemii rower, skuter czy UTO są alternatywą dla transportu zbiorowego w mieście i podobnie jak samochód zmniejszają prawdopodobieństwo zakażenia się niebezpiecznym wirusem. Samochód indywidualny ma bezsprzecznie wiele zalet, lecz nadmiar samochodów indywidualnych w miastach prowadzi do kongestii i wywołuje niepożądane zjawiska środowiskowe. Z kolei pojazdy jednośladowe, w tym UTO, są wrażliwe na pory roku i zjawiska atmosferyczne, nie są też popularne wśród osób starszych lub niedołężnych.

Wnioskuje się, że w sytuacji, gdy nie widać końca pandemii, przemieszczanie się z użyciem UTO jest sposobem na zmniejszenie ryzyka zarażenia (zob. Naka, 2020). UTO to także szansa na ograniczenie wzmożonego ruchu samochodami, zatem i oszczędność czasu podróży.

Sytuacja ta dotyczy nie tylko indywidualnych UTO, ale też hulajnóg współdzielonych pomimo problemów, które ze sobą niosą (bezpieczeństwo epidemiczne, niedbałe parkowanie, brak uregulowań prawnych i inne). Podobnie jak transport publiczny, tak i dostawcy mikromobilności biorą na siebie odpowiedzialność za bezpieczeństwo epidemiczne użytkowników poprzez ciągłą higienę i dezynfekcję (zob. Bao, 2020; Klimkowski, 2020). Zapewnienie tego bezpieczeństwa jest warunkiem koniecznym, aby użytkownicy mogli korzystać z mikromobilności współdzielonej (Olek, 2020).

Wzrost popularności UTO i rowerów zwiększa zjawisko rywalizacji pomiędzy pieszymi, użytkownikami mikromobilności i kierowcami samochodów o przestrzeń do poruszania się w mieście. Zapotrzebowanie na indywidualne przemieszczanie się w miastach, stymulowane pandemią koronawirusa, powinno przyśpieszyć rozwój urbanistyki taktycznej, który pozwoli na rozrzedzenie ruchu rowerowego poprzez zaanektowanie części jezdni na tymczasowe pasy rowerowe zwane pop-up bike lanes. W takich pasach znalazłoby się miejsce dla wszystkich środków transportowych 
mikromobilności (zob. Mayor Keisha Lance Bottoms Announces Action Plan for Safer Streets Across Atlanta Safety additions to over 20 miles of streets and tripling the city's protected bike lanes, 2019; Lit lanes now, 2020; Mayor's bold new Streetspace plan will overhaul London's streets, 2020; Reid, 2020). Polska nie pozostaje w tyle za podobnym trendem zaczęły podążać nasze duże miasta, takie jak Kraków, Warszawa czy Poznań (Urbanowicz, 2020; Chca tymczasowych pasów dla rowerów na jezdniach. Wskazują miejsca, 2020).

Być może, jak konkluduje Z. Domaszewicz (2020), czasowe modyfikacje przestrzeni drogowej, doraźnie zmieniające proporcje przydziału przestrzeni drogowej dla ruchu samochodowego i mikromobilnego, zaczną być z czasem stosowane regularnie. Można sobie to wyobrazić na przykład jako rozwiązania na okres wakacyjny, kiedy ruch samochodów w mieście nieco maleje, za to warunki sprzyjają jeździe na elektrycznych hulajnogach czy rowerach.

\section{Podsumowanie}

Definicja urządzenia transportu osobistego - UTO - formalnie nie została jeszcze zatwierdzona. Nie ma zatem urzędowych wymagań odnośnie konstrukcji UTO ani jego wyposażenia. Nie jest też określone, gdzie można takimi urządzeniami jeździć. UTO trudno ująć w formalne ramy przepisów, co z punktu widzenia użytkowników jest i zaletą, i wadą. Ustawodawca pracuje nad stosowną ustawą od lat, a ostateczna faza prac trwa już dość długo. Z jednej strony UTO korzystają z infrastruktury dla pieszych, a z drugiej - nie są równorzędne z innymi pojazdami, na przykład rowerami, motorowerami czy motocyklami.

UTO, podobnie jak inne mikropojazdy, z racji swej natury nie zapewniają bezpieczeństwa w razie kolizji czy wypadku i nie chronią kierującego podczas upadku. Aby ograniczyć potencjalne zagrożenia, należy przestrzegać następujących zasad: korzystać z kasku i ochraniaczy, zachować bezpieczną prędkość, nie poruszać się po jezdniach i zatłoczonych chodnikach, zwracać uwagę na pieszych i pamiętać o ograniczonym zaufaniu, korzystać z pojazdu wyłącznie w pojedynkę, dobrać pojazd odpowiedni do wzrostu i wagi, o optymalnej mocy silnika lub z możliwością ograniczenia prędkości, parkować tylko w bezpiecznych miejscach, najlepiej na uboczu.

Użytkowanie rowerów, hulajnóg i innych mikropojazdów już przed pandemią COVID-19 stało się preferowanym sposobem przemieszczania się w wielu miastach na świecie. W czasie trwania pandemii rower, skuter czy UTO są alternatywą dla transportu zbiorowego w mieście i podobnie jak samochód zmniejszają prawdopodobieństwo zakażenia się niebezpiecznym koronawirusem. Pandemia COVID-19 tylko przyspieszyła potrzebę wzięcia pod lupę ruchu w miastach. Mikromobilność oferuje bezpieczne i zrównoważone rozwiązanie - tym bardziej teraz, w czasach dystansu społecznego. 


\section{Bibliografia}

10 Recommendations for Safe Micromobility (2020), https://www.itf-oecd.org/10-recommendations-safe-micromobility [dostęp: 23.07.2020].

Bao B. (2020), Healthy People = Healthy Cities, https://v1.li.me/second-street/ healthy-people-healthy-cities [dostęp: 25.07.2020].

Bobek Ł. (2020), Tatry nie dla elektrycznych hulajnóg. TPN zakazał jazdy tym sprzętem, https://gazetakrakowska.pl/tatry-nie-dla-elektrycznych-hulajnog-tpn -zakazal-jazdy-tym-sprzetem/ar/c1-15049348 [dostęp: 22.07.2020].

Chca tymczasowych pasów dla rowerów na jezdniach. Wskazują miejsca (2020), https://tvn24.pl/tvnwarszawa/najnowsze/koronawirus-w-warszawie-chca -tymczasowych-pasow-dla-rowerow-4573164 [dostęp: 25.07.2020].

Dockless Electric Scooter-Related Injuries Study (2018), https://www.austintexas. gov/sites/default/files/files/Health/Epidemiology/APH_Dockless_Electric Scooter Study 5-2-19.pdf [dostęp: 24.07.2020].

Domaszewicz Z. (2020), Miasta po pandemii. Scenariusz dla mikromobilności, https://smartride.pl/miasta-po-pandemii-scenariusz-dla-mikromobilnosci/ [dostęp: 24.07.2020].

E-hulajnogi. Sharing. Polska. Trzeci kwartat 2020 roku (2020), https://smartride.pl/ Strefa_Danych/e-hulajnogi-sharing-polska-dane-trzeci-kwartal-2020-roku/ [dostęp: 22.07.2020].

Gitlin J.M. (2019), Head injuries, broken bones plague e-scooter users as more data rolls in, https://arstechnica.com/cars/2019/05/head-injuries-broken-bonesplague-e-scooter-users-as-more-data-rolls-in/ [dostęp: 24.07.2020].

Janczewski J. (2020), Mikromobilność - wybrane problemy, „Zarządzanie Innowacyjne w Gospodarce i Biznesie", nr 1/(28).

Janczewski J., Janczewska D. (2020), Zrównoważony rozwój z perspektywy mikromobilności, ,Zarządzanie Innowacyjne w Gospodarce i Biznesie”, nr 2/(29).

Jest szansa na uporzadkowanie bałaganu hulajnogowego (2020), https://www. prawodrogowe.pl/informacje/rozmowy/jest-szansa-na-uporzadkowanie-balaganu-hulajnogowego [dostęp: 20.07.2020].

Klimkowski M. (2020), Czy da się bezpiecznie jeździć hulajnoga podczas epidemii?, https://auto.wprost.pl/aktualnosci/10319102/czy-da-sie-bezpiecznie-jezdzic -hulajnoga-podczas-epidemii.html [dostęp: 25.07.2020].

Lit lanes now (2020), www.atlantabike.org/lit_lanes_now [dostęp: 23.07.2020].

Mayor Keisha Lance Bottoms Announces Action Plan for Safer Streets Across Atlanta Safety additions to over 20 miles of streets and tripling the city's protected bike lanes (2019), https://www.atlantaga.gov/Home/Components/News/ News/13144/672 [dostęp: 24.07.2020].

Mayor's bold new Streetspace plan will overhaul London's streets (2020), https:// www.london.gov.uk/press-releases/mayoral/mayors-bold-plan-will-overhaul-capitals-streets [dostęp: 25.07.2020]. 
Naka M. (2020), COVID-19 Reveals How Micromobility Can Build Resilient Cities, https://nextcity.org/daily/entry/covid-19-reveals-how-micromobility-can-build-resilient-cities [dostęp: 25.07.2020].

Olek J. (2020), Pandemia to szansa na miejska rewolucję w komunikacji, https://www. forbes.pl/opinie/przyszlosc-transportu-miejskiego-po-covid-19/27swrd5 [dostęp: 25.07.2020].

PKD o UTO: Nie tylko elektryczne (2020), https://kongresdrogowy.pl/post/677-pkd -o-uto-nie-tylko-elektryczne [dostęp: 23.07.2020].

Planujesz zakup e-pojazdu - przeczytaj koniecznie projekt ustawy o UTO (2020), https://techno-senior.com/2020/06/15/trendy-w-e-pojazdach-a-wymogi-projektu-ustawy-o-urzadzeniach-transportu-osobistego-uto/ [dostęp: 20.07.2020].

Polska może być krajem UTO. Badanie pokazało bardzo pozytywny stosunek do elektrycznej mobilności (2020), https://smartride.pl/polska-moze-byc-krajem-uto-badanie-stosunku-polakow-do-elektrycznej-mikromobilnosci/ [dostęp: 25.07.2020].

Poradnik. Bezpieczna jazda na hulajnodze (2020), https://electricfeel.pl/blog/bezpieczna-jazda-na-hulajnodze-elektrycznej/ [dostęp: 22.07.2020].

Projekt z dnia 12 maja 2020 r. Ustawy o zmianie Ustawy - Prawo o ruchu drogowym oraz niektórych innych ustaw (2020), https://legislacja.rcl.gov.pl/ projekt/12333706/katalog/12686566 [dostęp: 20.07.2020].

Reid C. (2020), Greater Manchester To Spend £5 Million On Pop-Up Cycleways, Widened Sidewalks, https://www.forbes.com/sites/carltonreid/2020/05/06/ greater-manchester-to-spend-5-million-on-pop-up-cycleways-widened-sidewalks/\#47987d9d19e [dostęp: 25.07.2020].

Rowerowy boom w Polsce: Dystans plus wakacje w kraju (2020), http://infobike. pl/rowerowy-boom-w-polsce-dystans-plus-wakacje-w kraju more 125727. html [dostęp: 24.07.2020].

Stanowiska zgłoszone w ramach konsultacji publicznych (2020), https://legislacja. rcl.gov.pl/projekt/12333706/katalog/12686566 [dostęp: 20.07.2020].

Szczęsny J. (2019), Elektryczne hulajnogi sa niebezpieczne. Musimy coś z nimi zrobic', https://antyweb.pl/elektryczne-hulajnogi-niebezpieczne/ [dostęp: 24.07.2020].

Szymaniak P. (2020), Pijana kobieta zmarła po wypadku na elektrycznej hulajnodze. RPO dopytuje o UTO, https://prawo.gazetaprawna.pl/artykuly/1486593, elektryczna-hulajnoga-przepisy-rpo.html [dostęp: 22.07.2020].

Śmierć na hulajnodze. To gdzie utknęła ustawa? (2020), https://www.prawodrogowe. pl/informacje/przeglad-prasy/smierc-na-hulajnodze-to-gdzie-utknela-ustawa [dostęp: 20.07.2020].

Urbanowicz W. (2020), Rewolucja w Krakowie. Będa tymczasowe pasy rowerowe w jezdni, https://www.transport-publiczny.pl/mobile/rewolucja-w-kra- 
kowie-beda-tymczasowe-pasy-rowerowe-w-jezdni-64463.html [dostęp: 25.07.2020].

Ustawa z dnia 20 czerwca 1997 r. - Prawo o ruchu drogowym, Dz.U. 2020, poz. $110 \mathrm{z}$ późn. zm.

UTO-entuzjaści. Urządzenia transportu osobistego i ich przyszłość w ocenie Polaków (2020), Stowarzyszenie Mobilne Miasto, https://mobilne-miasto.org/ news/badanie-uto/\# [dostęp: 3.11.2020].

\section{Summary \\ Safety problems of personal mobility devices}

Personal Mobility Devices are most often used for commuting to or returning from work, school, university, commuting to offices, as a connection with public transport, for social and recreational purposes. PMD are also used to move around office corridors, exhibition and industrial halls.

The key challenges for such forms of travel are infrastructure affordability, speed limits, weather sensitivity, lack of luggage and passenger space, battery charging, developing a favourable business and operational model. There are also significant concerns about legal compliance and challenges related to the safety of pedestrians and other road users and, recently, epidemiological safety.

This article aims to present some aspects of safety in relation to the use of personal transport devices both from the perspective of road traffic and from the perspective of epidemiology. The work is descriptive and presents four current and therefore important issues regarding personal transport devices. The first is the legal framework for defining and using PMD, the second is the research on the popularity of these devices in Poland, and the other two relate to selected safety issues of their use.

Keywords: personal mobility devices, micromobility, microvehicles, safety 